\title{
Cultivation and Propagation of Iris laevigata Fisch., an Endangered Ethno-medicinal Plant of Imphal Valley Manipur, India
}

\author{
S. Sanjay Singh ${ }^{1}$, Rocky Thokchom ${ }^{2}$, Jenita Thokchom ${ }^{2}$, Soumitra Sankar Das ${ }^{3}$, Arvind S. Dhabe \\ \& P. Kumar Singh ${ }^{4}$ \\ ${ }^{1}$ Department of Botany, Dr. Babasaheb Ambedkar Marathwada University, Aurangabad, Maharashtra, India \\ ${ }^{2}$ Department of Horticulture, South Asian Institute of Agricultural Management, Imphal, Manipur, India \\ ${ }^{3}$ Department of Agicultural Statistics, Birsa Agricultural University, Kanke Ranchi, Jharkhand, India \\ 4 Department of Life Sciences, Manipur University, Imphal, Manipur, India \\ Correspondence: S. Sanjay Singh, Department of Botany, Dr. Babasaheb Ambedkar Marathwada University, \\ Aurangabad-431004, Maharashtra, India. E-mail: estatecellmanipur@gmail.com
}

Received: February 28, $2021 \quad$ Accepted: March 25, $2021 \quad$ Online Published: April 15, 2021

doi:10.5539/jas.v13n5p153 URL: https://doi.org/10.5539/jas.v13n5p153

\begin{abstract}
Iris laevigata Fisch., is restricted geographically in Manipur, north eastern India. An experiment was planned with Factorial Randomized Block Design during 2018 to 2020 (3 seasons) in the study plots of ICAR Research Complex for NEH Region, Manipur Centre, Lamphelpat. The study encompasses on the growth and development of I. laevigata seedlings collected from Ipa Thoukok Complex: influenced by spacing, trimming and correlations amongst the growth parameters, so as to validate the most favourable conservation method for this endangered plant. Among the treatments, $\mathrm{T}_{6}=\mathrm{S}_{2} \mathrm{~T}_{3}(45 \mathrm{~cm} \times$ trimming $40 \mathrm{DAT})$ was found the best treatment. $\mathrm{T}_{9}=\mathrm{S}_{3} \mathrm{~T}_{3}(60 \mathrm{~cm} \times$ trimming $40 \mathrm{DAT})$ was second, $\mathrm{T}_{3}=\mathrm{S}_{1} \mathrm{~T}_{3}(30 \mathrm{~cm} \times \operatorname{trimming} 40 \mathrm{DAT})$ was the third and lowest was found in case of $\mathrm{T}_{1}=\mathrm{S}_{1} \mathrm{~T}_{1}(30 \mathrm{~cm} \times 0$ trimming, i.e., without trimming $)$. Strong positive correlation between leaf surface area and plant height on the growth and development was found to be effective among other correlations.
\end{abstract}

Keywords: Iris laevigata Fisch., endangered, growth and development, correlation, soil nutrient, water quality and depth

\section{Introduction}

Water Iris Plant: Iris laevigata Fisch., belongs to the family Iridaceae, grows in moist habitats like marshy grassy slopes, meadowlands, bogs and lakes. The plant is commonly known as Water Iris, Kombirei in Manipuri, Japanese iris, rabbit-ear iris, or shallow-flowered iris, is native to Japan. Water Iris is distributed from Assam to Myanmar. In Manipur the plant grows naturally in Lamphel pat, Yaral pat, Loktak Lake, etc., as an endemic water plant presently in the endangered status under the RET (Rare Endangered and Threatened) category. The genus Iris comprises more than 300 herbaceous species, growing in the temperate regions of the northern hemisphere (Rodionenko, 1987).

Regarding Iris species, Kostrakiewicz (2000) studied the analysis of spatial horizontal structure of I. sibirica L. population on the station in Stanisławice near Bochnia. The studied species growing in wet habitats belongs to rare, legal protected plants in Poland. The distribution of the individuals within all phytocenosis as well as on $100 \mathrm{~m}^{2}$ selected area was presented.

Earlier in Manipur, I. laevigata was wrongly identified by some researchers as Iris bakeri Wall. (Deb, 1961a, 1961b; Sinha, 1996). However, one scientist H. B. Singh identified Kombirei after confirmation from RBG, Kew (Sobhapati, 2017). Four species of Iris were reported in Manipur. Unfortunately this beautiful flower, which has very close connections with the traditions of Manipuris since time immemorial, is facing a great threat due to lack of attention. Height is the major distinct differences between I. laevigata $(106.68 \mathrm{~cm})$ and I. singuinea $(60.96 \mathrm{~cm})$ besides their leaves. Singuinea has no straight leaves unlike Laevigata. Even though other species such as $I$. wattii, I. singuinea, I. kumaon grow wild in the State, this flower grows only in the wetlands of Lamphelpat and Loktak Lake. Interestingly, I. singuinea which is used as real Kombirei (I. laevigata Fisch.) during annual Cheiraoba festival in April is being cultivated in private nurseries in view of the huge public demand (Sobhapati, 2017). 
Lee et al. (2018) reported the effect of water levels and soil nutrients on the growth of endangered I. laevigata seedlings in Korea. The study was conducted to examine the effects of environmental conditions such as water levels and soil nutrient conditions on the growth and survival of I. laevigata seedlings. Complete submergence lowered the total number of leaves, biomass, and survival rates. A rise in soil nutrients increased overall seedling growth and increased tiller numbers via the promotion of asexual reproduction. The water level must be lower than the seedling height for effective growth and management of I. laevigata.

Earlier, water Iris grows naturally, when the monsoon comes in Manipur during March-April, however, without people's care these plants could complete its mature stage and blooms flower. One can understand that Kombirei will be available in the marshy areas, when we need the flower. But nowadays, because of urbanization, drying up of lakes, expansion of agricultural lands, etc., it is high time to take care and artificial human protection and conservation of the plant.

In this regard, an understanding of the life cycle of a plant, such as the method of reproduction, seed dispersion, germination, and survival conditions of seedlings is essential for the stable establishment of the species (Mahoney \& Rood, 1998). Here it can be mentioned that, water level is the most important factor affecting seedling survival and the establishment of submerged plants (Nicol \& Ganf, 2000; Fraser \& Karnezis, 2005; Kwon et al., 2007; Casanova \& Brock, 2000).

From China, Wang et al. (2017) observed the plant growth parameters between reproductive ramets and non-reproductive ramets and reported that leaves of reproductive ramets stopped growing around the time that flowering began (in late May), while the leaves of non-reproductive ramets would continue growing until late August, dramatically increasing the leaf area available for photosynthesis.

In Manipur, there is continuous exploitation, habitat-degradation, unsustainable harvesting and over-exploitation bringing substantial loss of the habitat of I. laevigata, is still going on. Most problematic one is during the annual Cheiraoba festival, i.e., Annual New Year, which falls during the month of April, two Cheiraoba festivals are being observed: one on the day of Shajibu nongma panba for Meiteis, and another one, as Charak puja observed by the Meitei following Hinduism religion. On these two days Kombirei flower is being offered to the God as one of the most important constituents. On this day people purchase from the local market at Rs. 10 to 50 per bunch of Kombirei flower. People use to over harvest from the marshy natural home of Kombirei or from the market.

Some researchers from Manipur State worked on the distribution and mapping of some endangered plants and their status under the RET category (Devi \& Das, 2016; Singh et al., 2017, 2020; Devi et al., 2021). So far, no scientific work has been done regarding I. laevigata, which is endangered plant under the RET category. Here, we focused on the growth and development of I. laevigata seedlings with specific objectives of this paper as follows: (1) influenced by spacing, (2) trimming and (3) correlations amongst the growth parameters of the plant, so as to validate the most favourable conservation method for this endangered plant.

\section{Materials and Methods}

\subsection{Study Site}

The present work has been taken up to cultivate Water Iris plant, which is under the RET category, so as to conserve the plant species by following modern tools of agricultural practices under ICAR, Lamphelpat, Imphal; field condition of Ipa Thoukok Complex (Figure 1). 


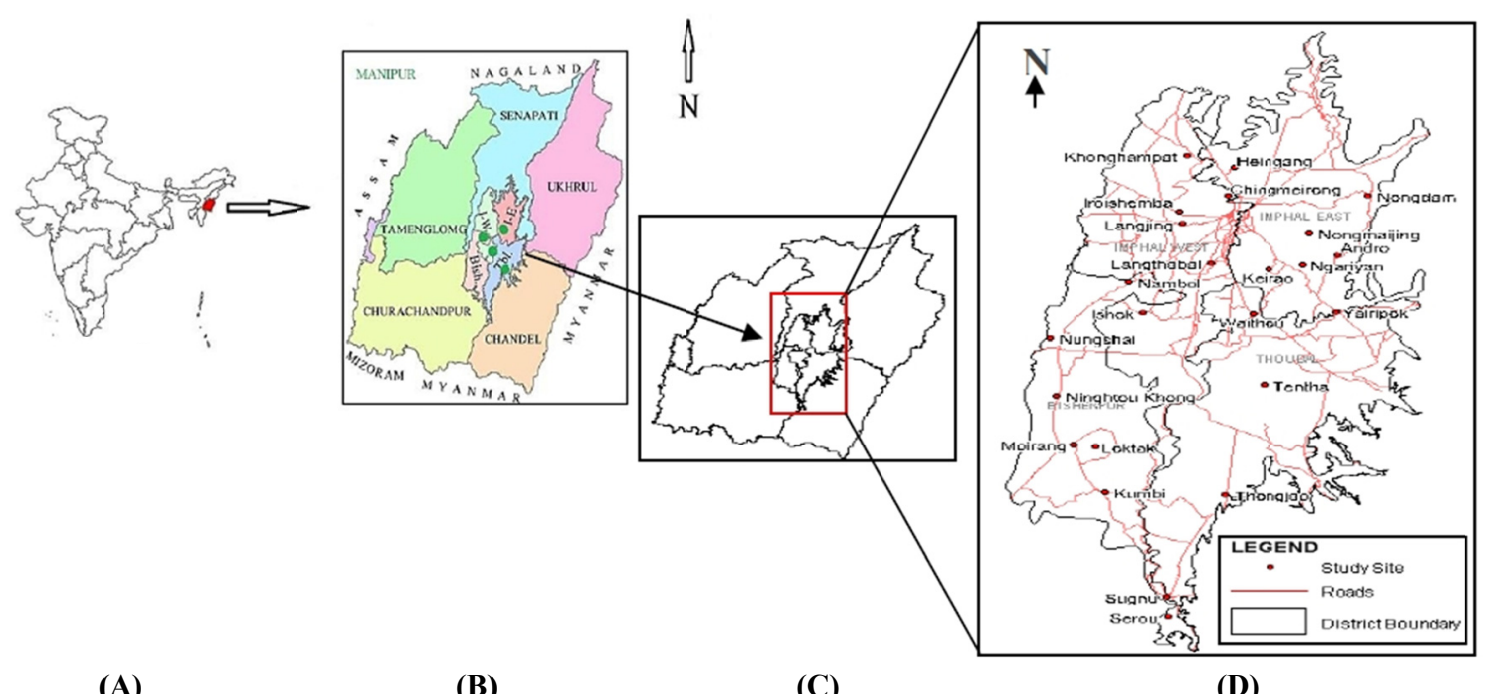

(A)

(B)

(C)

(D)

Figure 1. Study area: (A) Map of India showing the location of Manipur; (B) Map of Manipur showing districts;

(C) Map of Manipur showing the location of Imphal valley; (D) Map of Imphal valley and study sites ICAR, Lamphelpat

\subsection{Experimental Design}

Factorial Randomized Block Design was made with a Plot Size of $4.0 \mathrm{~m} \times 5.0 \mathrm{~m}$. The Layout Plan for the cultivation and propagation of Iris laevigata Fisch., was done during 2018 to 2020 (3 seasons) in the study plots of ICAR Research Complex for NEH Region, Manipur Centre, Lamphelpat, Imphal. Treatments: Two factors: Factor 1: Spacing 3 levels $\left(S_{1}=30 \mathrm{~cm}, S_{2}=45 \mathrm{~cm}, S_{3}=60 \mathrm{~cm}\right)$; Factor 2: Trimming 3 levels $\left(T_{1}=0\right.$ trimming, $\mathrm{T}_{2}=$ trimming 20 DAT (Days after Transplantation), $\mathrm{T}_{3}=$ trimming 40 DAT) (Table 1).

Table 1. Layout Plan for the Cultivation and Propagation of Iris laevigata Fisch

\begin{tabular}{|c|c|c|c|}
\hline \multicolumn{4}{|c|}{ Plot Size: $4.0 \mathrm{~m} \times 5.0 \mathrm{~m}$} \\
\hline \multicolumn{4}{|c|}{ Design: Factorial Randomized Block Design } \\
\hline \multicolumn{4}{|c|}{ Treatment: } \\
\hline \multicolumn{4}{|c|}{ Factor 1: Spacing 3 levels: $\left(\mathrm{S}_{1}=30 \mathrm{~cm}, \mathrm{~S}_{2}=45 \mathrm{~cm}, \mathrm{~S}_{3}=60 \mathrm{~cm}\right)$; } \\
\hline \multicolumn{4}{|c|}{ Factor 2: Trimming 3 levels: $\left(\mathrm{T}_{1}=0\right.$ trimming, $\mathrm{T}_{2}=$ trimming $20 \mathrm{DAT}, \mathrm{T}_{3}=$ trimming $\left.40 \mathrm{DAT}\right)$} \\
\hline \multicolumn{3}{|c|}{ Rows (R) } & \multirow{2}{*}{ Treatments } \\
\hline $\mathbf{R}_{\mathbf{1}}$ & $\mathbf{R}_{\mathbf{2}}$ & $\mathbf{R}_{\mathbf{3}}$ & \\
\hline $\mathrm{T}_{5}$ & $\mathrm{~T}_{6}$ & $\mathrm{~T}_{3}$ & $\mathrm{~T}_{1}=\mathrm{S}_{1} \mathrm{~T}_{1}(30 \mathrm{~cm} \times 0$ trimming $)$ \\
\hline $\mathrm{T}_{3}$ & $\mathrm{~T}_{4}$ & $\mathrm{~T}_{5}$ & $\mathrm{~T}_{2}=\mathrm{S}_{1} \mathrm{~T}_{2}(30 \mathrm{~cm} \times$ trimming $20 \mathrm{DAT})$ \\
\hline $\mathrm{T}_{9}$ & $\mathrm{~T}_{8}$ & $\mathrm{~T}_{7}$ & $\mathrm{~T}_{3}=\mathrm{S}_{1} \mathrm{~T}_{3}(30 \mathrm{~cm} \times$ trimming $40 \mathrm{DAT})$ \\
\hline $\mathrm{T}_{6}$ & $\mathrm{~T}_{9}$ & $\mathrm{~T}_{6}$ & $\mathrm{~T}_{4}=\mathrm{S}_{2} \mathrm{~T}_{1}(45 \mathrm{~cm} \times 0$ trimming $)$ \\
\hline $\mathrm{T}_{1}$ & $\mathrm{~T}_{1}$ & $\mathrm{~T}_{1}$ & $\mathrm{~T}_{5}=\mathrm{S}_{2} \mathrm{~T}_{2}(45 \mathrm{~cm} \times$ trimming $20 \mathrm{DAT})$ \\
\hline $\mathrm{T}_{4}$ & $\mathrm{~T}_{7}$ & $\mathrm{~T}_{4}$ & $\mathrm{~T}_{6}=\mathrm{S}_{2} \mathrm{~T}_{3}(45 \mathrm{~cm} \times$ trimming $40 \mathrm{DAT})$ \\
\hline $\mathrm{T}_{8}$ & $\mathrm{~T}_{5}$ & $\mathrm{~T}_{2}$ & $\mathrm{~T}_{7}=\mathrm{S}_{3} \mathrm{~T}_{1}(60 \mathrm{~cm} \times 0$ trimming $)$ \\
\hline $\mathrm{T}_{2}$ & $\mathrm{~T}_{3}$ & $\mathrm{~T}_{9}$ & $\mathrm{~T}_{8}=\mathrm{S}_{3} \mathrm{~T}_{2}(60 \mathrm{~cm} \times$ trimming $20 \mathrm{DAT})$ \\
\hline $\mathrm{T}_{7}$ & $\mathrm{~T}_{2}$ & $\mathrm{~T}_{8}$ & $\mathrm{~T}_{9}=\mathrm{S}_{3} \mathrm{~T}_{3}(60 \mathrm{~cm} \times$ trimming $40 \mathrm{DAT})$ \\
\hline
\end{tabular}

\subsection{Physico-chemical Soil and Water Composition}

Soil and water samples of the experimental plots were analyzed at ICAR Research Complex for NEH Region, Manipur Centre, Lamphelpat, Imphal. 


\subsection{Meteorological Data}

Meteorological Data of the experimental farm was recorded from ICAR Complex during the tenure of the research program. Soil and water analysis of the experimental farms were analysed at ICAR Research Complex for NEH Region, Manipur Centre, Lamphelpat, Imphal. In Manipur there are four marked seasons namely, spring (March-May), rainy (June-Aug.), summer (Sept.-Nov.) and winter (Dec.-Feb.); because of the fluctuation and changing environment, each and every seasons overlapping each other (Figure 2).

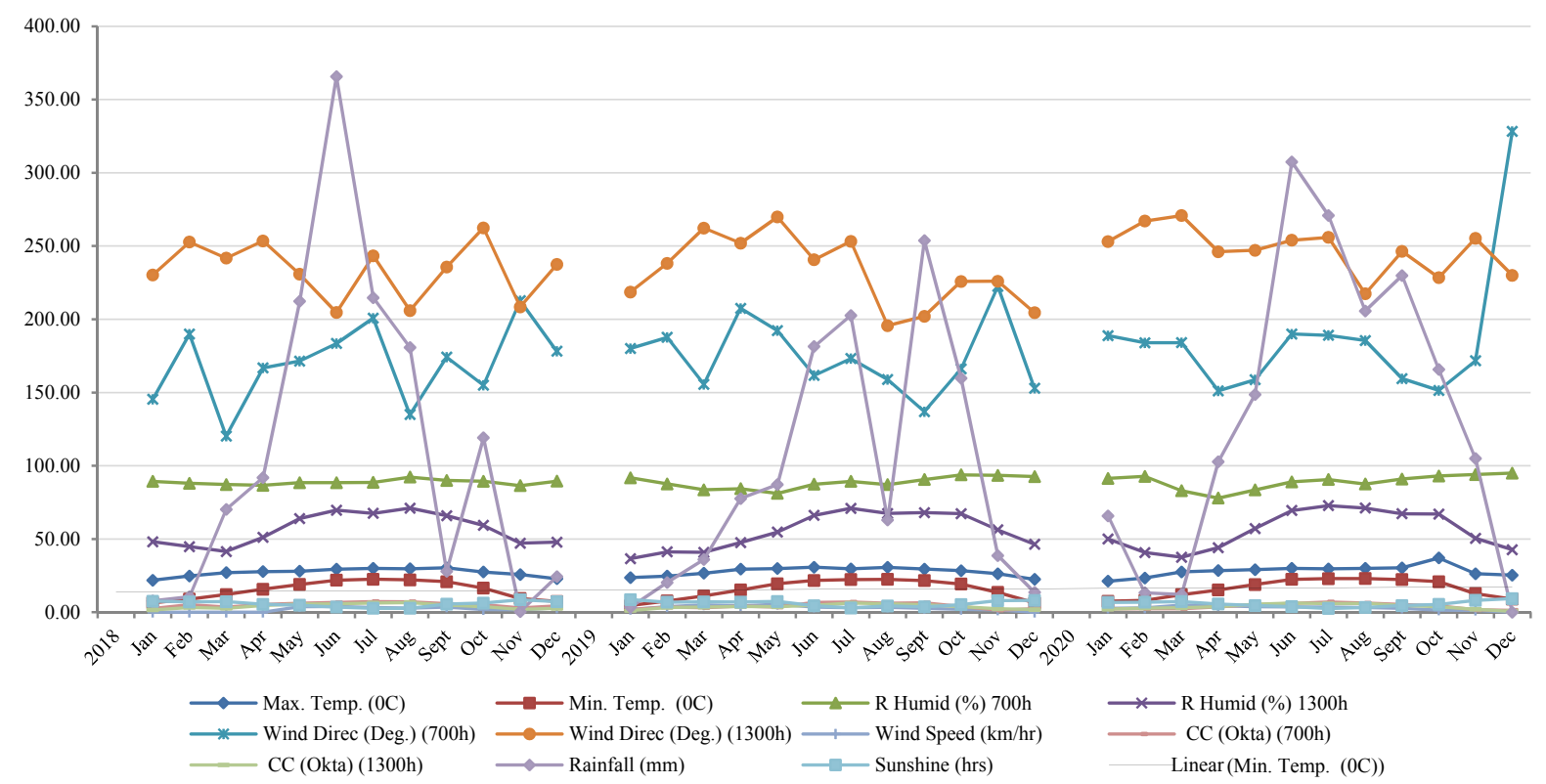

Figure 2. Weather data of Iris laevigata Fisch., experimental farm at ICAR Research Complex, Lamphelpat, Imphal from 2018 to 2020

\subsection{Plant Growth Parameters}

Plantation of water iris was done in the month of July, trimming started after 20 and 40 DAT, avoid cutting of leaves completely as the rhizomes will need some foliage to collect nutrients and recover from the transplant shock. The leaf will develop erectly after the transplantation in the field. The leaf surface area, plant height, number of leaves, number of plants per clump, number of flowers per pike, number of rhizomes per clump, etc., will be measured. The correlations between plant height and leaf surface area and other growth parameters will be calculated. Flowering will be during the month of March to May and harvesting follows.

\subsection{Statistical Anlysis}

All the analyses were carried out using SPSS 22.0 for Windows (SPSS, Inc., Chicago, Illinois, USA). The experiment was laid out under factorial randomized block design. The data were analyzed by Fisher's analysis of variance (ANOVA) technique and then results were interpreted.

\section{Results and Discussion}

In Table 2, among the treatments, $\mathrm{T}_{6}=\mathrm{S}_{2} \mathrm{~T}_{3}(45 \mathrm{~cm} \times$ trimming $40 \mathrm{DAT})$ was found the best treatment. $\mathrm{T}_{9}=\mathrm{S}_{3} \mathrm{~T}_{3}$ $(60 \mathrm{~cm} \times$ trimming $40 \mathrm{DAT})$ was second, $\mathrm{T}_{3}=\mathrm{S}_{1} \mathrm{~T}_{3}(30 \mathrm{~cm} \times$ trimming $40 \mathrm{DAT})$ was the third and lowest was found in case of $\mathrm{T}_{1}=\mathrm{S}_{1} \mathrm{~T}_{1}(30 \mathrm{~cm} \times 0$ trimming, i.e., without trimming). From the results it can be concluded that, in water iris cultivation spacing of $45 \mathrm{~cm}$ with trimming at 40 DAT treatment $\mathrm{T}_{6}$ was the best and whereas, lowest value of treatment $T_{1}$ in which $30 \mathrm{~cm}$ spacing without trimming is unfavorable for the growth of water iris. The plant can grow luxuriantly in the ICAR Experimental Farm, Lamphelpat with the Treatment No. $\mathrm{T}_{6}=\mathrm{S}_{2} \mathrm{~T}_{3}$ (45 $\mathrm{cm} \times$ trimming 40 DAT) (Table 2).

Soil $\mathrm{pH}$ value was 5.8; E.C. was 0.048 ; organic carbon was $3.76 \%$; available N, P and $\mathrm{K}$ were found to be 615 , 28 and $920 \mathrm{~kg}$ /ha respectively. Some micronutrients viz., $\mathrm{Cu}, \mathrm{Fe}, \mathrm{Zn}$ and $\mathrm{Mn}$ ranges from 0.4, 80.4, 2.5 and 40.50 $\mathrm{mg} / \mathrm{kg}$ respectively. Water $\mathrm{pH}$ value was 7.26 ; E.C. was $0.48 ; \mathrm{P}$ and $\mathrm{K}$ ranges from 0.014 and $14.7 \mathrm{ppm}$ respectively. 
Table 2. Influence of spacing and trimming on growth and development of Iris laevigata Fisch.

\begin{tabular}{|c|c|c|c|c|c|c|c|c|c|c|}
\hline Treatment & $\begin{array}{l}\text { Plant } \\
\text { height } \\
(\mathrm{cm})\end{array}$ & $\begin{array}{l}\text { No. of } \\
\text { leaves/ } \\
\text { plant }\end{array}$ & $\begin{array}{l}\text { No. of } \\
\text { plants/ } \\
\text { clump }\end{array}$ & $\begin{array}{l}\text { Days } \\
\text { to spike } \\
\text { emergence }\end{array}$ & $\begin{array}{l}\text { Days } \\
\text { to flower } \\
\text { initiation }\end{array}$ & $\begin{array}{l}\text { No. of } \\
\text { spikes/ } \\
\text { plant }\end{array}$ & $\begin{array}{l}\text { No. of } \\
\text { flowers/ } \\
\text { spike }\end{array}$ & $\begin{array}{l}\text { Spike } \\
\text { length } \\
(\mathrm{cm})\end{array}$ & $\begin{array}{l}\text { No. of } \\
\text { rhizomes/ } \\
\text { clump }\end{array}$ & $\begin{array}{l}\text { Weight } \\
\text { of rhizome } \\
\text { (g) }\end{array}$ \\
\hline \multicolumn{11}{|l|}{ Year $(Y)$} \\
\hline$Y_{1}-2018$ & 56.207 & 15.488 & 6.363 & 247.934 & 9.635 & 3.302 & 3.180 & 48.474 & 6.363 & 94.074 \\
\hline$Y_{2}-2019$ & 56.905 & 15.423 & 7.626 & 247.749 & 9.693 & 3.556 & 3.780 & 55.327 & 7.626 & 99.249 \\
\hline $\mathrm{Y}_{3}-2020$ & 58.329 & 17.643 & 8.437 & 249.737 & 9.869 & 4.129 & 3.375 & 54.564 & 8.437 & 100.881 \\
\hline S.E $(m) \pm$ & 1.510 & 0.364 & 0.201 & 1.427 & 0.286 & 0.133 & 0.114 & 0.867 & 0.201 & 1.873 \\
\hline C.D. at $5 \%$ & NS & 1.036 & 0.573 & NS & NS & 0.379 & 0.325 & 2.464 & 0.573 & NS \\
\hline \multicolumn{11}{|l|}{ Spacing (S) } \\
\hline $\mathrm{S}_{1}(30 \mathrm{~cm})$ & 48.170 & 12.509 & 5.437 & 253.883 & 10.129 & 3.410 & 3.282 & 48.774 & 5.437 & 79.241 \\
\hline $\mathrm{S}_{2}(45 \mathrm{~cm})$ & 60.659 & 16.762 & 6.941 & 243.983 & 9.251 & 3.854 & 3.411 & 54.417 & 6.941 & 103.725 \\
\hline $\mathrm{S}_{3}(60 \mathrm{~cm})$ & 62.613 & 19.284 & 10.048 & 247.553 & 9.817 & 3.723 & 3.640 & 55.173 & 10.048 & 111.237 \\
\hline S.E $(m) \pm$ & 1.510 & 0.364 & 0.201 & 1.427 & 0.286 & 0.133 & 0.114 & 0.867 & 0.201 & 1.873 \\
\hline C.D. at $5 \%$ & 4.294 & 1.036 & 0.573 & 4.059 & NS & NS & NS & 2.464 & 0.573 & 5.327 \\
\hline \multicolumn{11}{|l|}{ Trimming $(T)$} \\
\hline $\mathrm{T}_{1}$ (No trimming) & 51.936 & 14.011 & 6.578 & 259.572 & 10.907 & 3.011 & 2.961 & 47.983 & 6.578 & 92.442 \\
\hline $\mathrm{T}_{2}(20 \mathrm{DAT})$ & 56.864 & 15.961 & 7.400 & 246.933 & 9.503 & 3.634 & 3.492 & 51.902 & 7.400 & 97.926 \\
\hline $\mathrm{T}_{3}(40 \mathrm{DAT})$ & 62.641 & 18.582 & 8.448 & 238.913 & 8.788 & 4.341 & 3.881 & 58.480 & 8.448 & 103.836 \\
\hline $\operatorname{S.E}(\mathrm{m}) \pm$ & 1.510 & 0.364 & 0.201 & 1.427 & 0.286 & 0.133 & 0.114 & 0.867 & 0.201 & 1.873 \\
\hline C.D. at $5 \%$ & 4.294 & 1.036 & 0.573 & 4.059 & 0.813 & 0.379 & 0.325 & 2.464 & 0.573 & 5.327 \\
\hline \multicolumn{11}{|l|}{ Interaction (SXT) } \\
\hline $\mathrm{S}_{1} \mathrm{~T}_{1}$ & 43.179 & 11.411 & 4.956 & 266.103 & 11.803 & 2.800 & 2.609 & 42.799 & 4.956 & 70.970 \\
\hline $\mathrm{S}_{1} \mathrm{~T}_{2}$ & 47.813 & 12.467 & 5.511 & 250.677 & 9.807 & 3.460 & 3.429 & 48.851 & 5.511 & 79.476 \\
\hline $\mathrm{S}_{1} \mathrm{~T}_{3}$ & 53.517 & 13.650 & 5.844 & 244.869 & 8.778 & 3.971 & 3.809 & 54.673 & 5.844 & 87.279 \\
\hline $\mathrm{S}_{2} \mathrm{~T}_{1}$ & 53.839 & 13.258 & 5.822 & 259.699 & 10.574 & 3.058 & 2.886 & 48.799 & 5.822 & 99.169 \\
\hline $\mathrm{S}_{2} \mathrm{~T}_{2}$ & 59.770 & 16.163 & 6.644 & 240.660 & 8.757 & 3.709 & 3.382 & 53.071 & 6.644 & 103.940 \\
\hline $\mathrm{S}_{2} \mathrm{~T}_{3}$ & 68.368 & 20.864 & 8.356 & 231.591 & 8.422 & 4.794 & 3.967 & 61.382 & 8.356 & 108.066 \\
\hline $\mathrm{S}_{3} \mathrm{~T}_{1}$ & 58.791 & 17.365 & 8.956 & 252.914 & 10.343 & 3.177 & 3.388 & 52.350 & 8.956 & 107.187 \\
\hline $\mathrm{S}_{3} \mathrm{~T}_{2}$ & 63.009 & 19.253 & 10.044 & 249.463 & 9.944 & 3.733 & 3.666 & 53.783 & 10.044 & 110.361 \\
\hline $\mathrm{S}_{3} \mathrm{~T}_{3}$ & 66.039 & 21.233 & 11.144 & 240.280 & 9.163 & 4.258 & 3.868 & 59.386 & 11.144 & 116.164 \\
\hline S.E $(m) \pm$ & 2.616 & 0.631 & 0.349 & 2.472 & 0.495 & 0.231 & 0.198 & 1.501 & 0.349 & 3.245 \\
\hline C.D. at $5 \%$ & NS & 1.794 & NS & NS & NS & NS & NS & NS & NS & NS \\
\hline C.V & 13.731 & 11.693 & 14.002 & 2.985 & 15.262 & 18.889 & 17.221 & 8.531 & 14.002 & 9.926 \\
\hline
\end{tabular}

Soil and Water samples for the cultivation of water iris should be maintained as follows: Soil $\mathrm{pH}$ value at 5.8; E.C. at 0.048 ; organic carbon $3.76 \%$; available N, P and K should be maintained as 615,28 and $920 \mathrm{~kg} / \mathrm{ha}$ respectively. Some micronutrients viz., $\mathrm{Cu}, \mathrm{Fe}, \mathrm{Zn}$ and $\mathrm{Mn}$ required from $0.4,80.4,2.5$ and $40.50 \mathrm{mg} / \mathrm{kg}$ respectively. Water $\mathrm{pH}$ value should be maintained at 7.26; E.C. at 0.48 ; $\mathrm{P}$ and $\mathrm{K}$ should be maintained from 0.014 and $14.7 \mathrm{ppm}$ respectively. Some micronutrients like, $\mathrm{Cu}, \mathrm{Fe}, \mathrm{Zn}$ and $\mathrm{Mn}$ content in water samples were found to be in trace amounts. In some places where water iris could not grow were low water level, eutrophic condition, alkaline $\mathrm{pH}$ of water and soil; and low nutrients (Figures 3 and 4). 


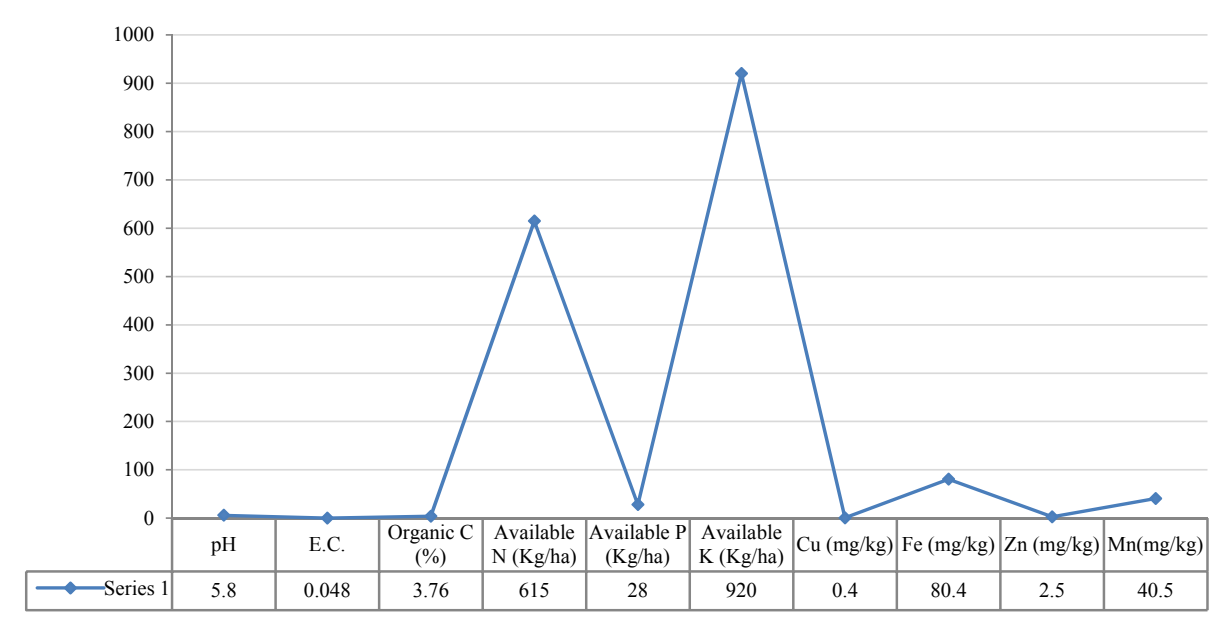

Figure 3. Soil analysis of the Experimental Fields of Iris laevigata Fisch. Lamphelpat

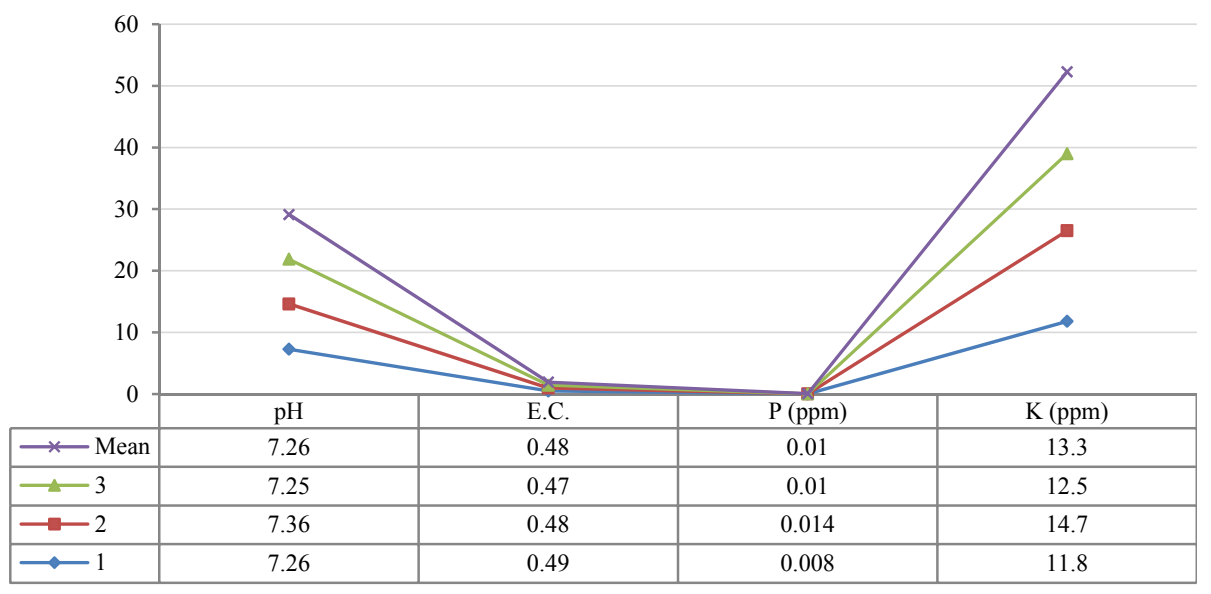

Figure 4. Water analysis of the Experimental Fields of Iris laevigata Fisch., Lamphelpat

As water iris is an aquatic plant with almost all the aerial half is above water in amphibious manner, maintenance of water level is mandatory for seedling growth. Submerged and flooding of water levels with eutrophic conditions are badly affected to the plant. So, any marshy and waterlogging areas are not suitable for Iris cultivation. Lacoul and Freedman (2006) supported this view and opined that "rapid seedling growth is required to quickly escape the stressful environment of submergence and low nutrient seedlings". Lee et al. (2018) reported the effect of water levels and soil nutrients on the growth of endangered Iris laevigata seedlings in Korea. A rise in soil nutrients increased overall seedling growth and increased tiller numbers via the promotion of asexual reproduction. The water level must be lower than the seedling height for effective growth and management of I. laevigata.

Environmental factors of Manipur State favours for the natural growth of water iris. The plant is a perennial plant with rhizomatous stalk keep drying as a dormant phase during winter (Dec.-Feb.), when monsoon (March-May) comes during the end of February month starts sprouting and has reached the mature stage and flowering begins during the first week of April and continues till May end. As there were fluctuations of meteorological data during the three crop seasons (2018 to 2020) of water iris maximum rainfall reach maximum during the month of July, however, in the year 2019 rainfall was meagre and attain maximum in October. Maximum and minimum temperatures also fluctuate every year. If so fluctuations could be seen during three crop seasons. Even though, the normal temperatures did not cross an average of $32{ }^{\circ} \mathrm{C}$ every year, the plant maintains its growth (Figure 2). 


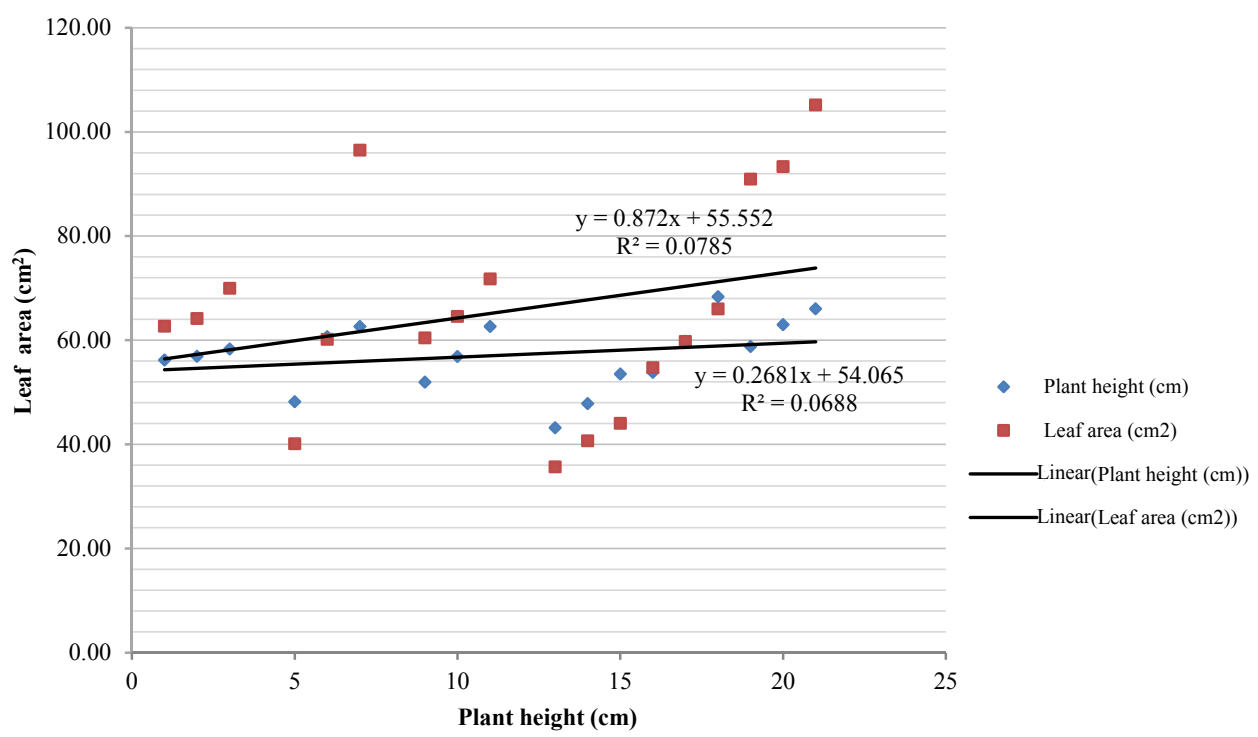

Figure 5. Correlation between leaf surface area and plant height on the growth and development of Iris laevigata Fisch.

Strong positive correlation between leaf surface area and plant height on the growth and development was found to be effective among other correlations (Figure 5). This work is in conformity with Wang et al. (2017), he reported that leaves of reproductive ramets stopped growing around the time that flowering began (in late May), while the leaves of non-reproductive ramets would continue growing until late August, dramatically increasing the leaf area available for photosynthesis.

\section{Conclusion}

From the above mentioned facts, scientific method of cultivation as an objective of conservation measures was done at ICAR Research Complex for NEH Region, Manipur Centre, Lamphelpat, Imphal. QPMs (Quality Planting Materials) were adopted in the present research program. Plant Growth Analysis and good harvesting techniques were also adopted to conserve the plant and the findings should be reached to the farmers. Water iris should be planted at a spacing of $45 \mathrm{~cm}$ during the month of July, trimming at 40 DAT (days after transplantation), flowering during March to May and harvesting of rhizomes followed.

\section{References}

Casanova, M. T., \& Brock, M. A. (2000). How do depth, duration, and frequency of flooding influence the establishment of wetland plant communities? Plant Ecology, 147(2), 237-250. https://doi.org/10.1023/ A:1009875226637

Deb, D. B. (1961a). Dicotyledonous plants of Manipur territory. Bulletin of Botanical Survey of India, 3.

Deb, D. B. (1961b). Monocotyledonous plants of Manipur Territory. Bulletin of Botanical Survey of India, 3.

Devi, K. Y., Singh, S. S., Devi, M. H., Dhabe, A. S., \& Singh, P. K. (2021). Ethno-medicinal Plants from Bishnupur District, Manipur, north eastern India. Bioinfolet, 17(4a), 602-608.

Devi, T. S., \& Das, A. K. (2016). Occurrence of some Rare and Threatened vascular plants in Senapati district, Manipur, Northeast India. NeBio, 7(3), 111-114.

Fraser, L. H., \& Karnezis, J. P. (2005). A comparative assessment of seedling survival and biomass accumulation for fourteen wetland plant species grown under minor water-depth differences. Wetlands, 25(3), 520-530. https://doi.org/10.1672/0277-5212(2005)025[0520:ACAOSS]2.0.CO;2

Kostrakiewicz, K. (2000). The analysis of special structure of Iris sibirica (Iridaceae) population on the station in Stanislawice near Bochniaouthern Poland. Fragm. Flor. Geobot. Polonica, 7, 209-214.

Kwon, G. J., Lee, B. A., Nam, J. M., \& Kim, J. G. (2007). The relationship of vegetation to environmental factors in Wangsuk stream and Gwarim reservoir in Korea: II. Soil environments. Ecological Research, 22(1), 75-86. https://doi.org/10.1007/s11284-006-0188-4 
Lacoul, P., \& Freedman, B. (2006). Environmental influences on aquatic plants in freshwater ecosystems. Environmental Reviews, 14(2), 89-136. https://doi.org/10.1139/a06-001

Lee, E. H., Lee, B. E., \& Kim, J. G. (2018). Effect of water levels and soil nutrients on the growth of Iris laevigata seedlings. Journal of Ecology and Environment, 42(5), 1-7. https://doi.org/10.1186/s41610-0180065-4

Mahoney, J. M., \& Rood, S. B. (1998). Streamflow requirements for cottonwood seedling recruitment—An integrative model. Wetlands, 18(4), 634-645. https://doi.org/10.1007/BF03161678

Nicol, J. M., \& Ganf, G. G. (2000). Water regimes, seedling recruitment and establishment in three wetland plant species. Marine and Freshwater Research, 51(4), 305-309. https://doi.org/10.1071/MF99147

Rodionenko, G. I. (1987). The genus Iris L.: Questions of morphology, biology, evolution and systematics. London: British Iris Society.

Singh, H. D., Ningombam, D., Singh, P. K., \& Borah, L. (2017). Status of Threatened Ethno-medicinal Plants Found in Sub-alpine areas of Ukhrul and Senapati Districts of Manipur. International Journal of Applied Research, 3(6), 544-548.

Singh, S. S., Devi, M. H., Dhabe, A. S., \& Singh, P. K. (2020). Status of Threatened Ethno-medicinal Plants from Imphal Valley (Manipur) India. Bioinfolet, 17(3a), 386-394.

Sinha, S. C. (1996). Medicinal plants of Manipur. Manipur Association for Science \& Society (MASS), Manasi Press, Calcutta.

Sobhapati, S. (2017). The Assam Tribune (26-04-2017). Guwahati, India.

Wang, L., Wang, H., He, C., Sheng, L., \& Tang, Z. (2017). An irreversible division of labour through a sexually dependent system in the clonal plant Iris laevigata (Iridaceae). Ecosphere, 8(3), 1-11. https://doi.org/ $10.1002 /$ ecs 2.1757

\section{Copyrights}

Copyright for this article is retained by the author(s), with first publication rights granted to the journal.

This is an open-access article distributed under the terms and conditions of the Creative Commons Attribution license (http://creativecommons.org/licenses/by/4.0/). 